\title{
Climate change: a friend or foe to food security in Africa?
}

\author{
Robert Becker Pickson ${ }^{1}$ (D . Elliot Boateng ${ }^{2,3}$
}

Received: 11 December 2020 / Accepted: 24 June 2021 / Published online: 10 July 2021

(c) The Author(s), under exclusive licence to Springer Nature B.V. 2021

\begin{abstract}
Extreme climate change is posing an increasing threat to human welfare across countries. Specifically, the devastating floods coupled with the looming spectre of drought are argued to explain cross-country differences in food security. While the debate continues and uncertainties about the precise influence of climate change on food security linger, the question of whether climate change plays a pivotal role in increased hunger and food insecurity across countries remains unanswered. This study presented new evidence of the role of climate change in Africa's food security. We utilised the Mann-Kendall test and Sen's slope estimator to analyse climate change trends. We also employed the pooled mean group technique and the Dumitrescu-Hurlin panel causality test to investigate the effect of climate change on food security in 15 African countries between 1970 and 2016. Our empirical findings revealed three things. First, rainfall plays a decisive role in Africa's food security when examined broadly. However, the significance of the effect of rainfall varied substantially across the 15 countries. Second, we find no robust impact of temperature on food security in the long run. However, the short-run results showed that extreme temperatures impede food security, with varying magnitudes across countries. Third, except for rainfall, a bidirectional causality exists between food security and temperature in Africa. Given the risks associated with rain-fed agriculture, we argue that African countries need to limit their dependence on rain-fed agriculture to boost food production.
\end{abstract}

Keywords Climate change $\cdot$ Climate variability $\cdot$ Food security $\cdot$ Cultivated area Population growth $\cdot$ Africa

Robert Becker Pickson myselfpickson@yahoo.com

Elliot Boateng

elliot.boateng@uon.edu.au

1 College of Management, Sichuan Agricultural University, Chengdu, China

2 Newcastle Business School, University of Newcastle, Newcastle, Australia

3 Centre for African Research, Engagement and Partnerships (CARE-P), University of Newcastle, Newcastle, Australia 


\section{Introduction}

The role of climate change in economic growth has dominated global policy discussions for many decades (Berrera \& Hertel, 2021; Chauhan et al., 2020; Food and Agriculture Organization [FAO] et al., 2019; Hossain et al., 2019; Intergovernmental Panel on Climate Change, 2001). Development practitioners and policymakers describe frequent climate variability as a menace and an obstacle to sustainable global growth and development (Boko et al., 2007; Murphy \& Drexhage, 2010). Despite these concerns, evidence shows that climate change has become more severe, and the drivers of greenhouse gases, such as carbon dioxide, methane, ozone, and nitrous oxide, are still on the rise, even with the global slowdown resulting from the COVID-19 pandemic (World Meteorological Organization, 2020). While a comprehensive assessment of the risks associated with changing climatic conditions remains controversial (McCarl et al., 2013), a growing number of studies examining the effects of climate change argue that upsurging greenhouse gases increase atmospheric temperatures, create extreme weather events, and threaten food production, especially in regions that depend extensively on rain-fed farming (Mendelsohn \& Wang, 2017; Sigh \& Thadani, 2015; Yobom, 2020). Thus, the relative effect of climate change on food security will be much higher in developing countries if it persists.

Recent evidence reveals an alarming rise in global hunger and undernourishment, alongside increasingly extreme climatic conditions. Approximately 690 million people went hungry in 2019, and this figure is expected to rise by 60 million people in the next five years (FAO et al., 2020). These sobering figures raise the question: can we still achieve the Sustainable Development Goals of eradicating hunger by 2030? (United Nations, 2015). While policy consensus is required to mitigate the prevailing symptoms of food insecurity, the underlying drivers of global food insecurity remain complex and inconclusive (Amekudzi et al., 2015; Chauhan et al., 2020; Hossain et al., 2019; Owusu et al., 2021). A plethora of studies associates hunger with changing farming activities imposed by the cumulative effects of climate change on all dimensions of food security-food access, availability, stability, and utilisation-across regions (Easterling et al., 2000; FAO, 2010; FAO et al., 2019; Hossain et al., 2019; McCarthy et al., 2001). For instance, extreme climate change and variability will decrease crop output in some African countries by up to $50 \%$ by 2030 , while crop income may decline by $90 \%$ by 2100 (Boko et al., 2007). Other studies suggest that climate change has already led to a decline in food security at national and household levels in developing countries (Connolly-Boutin \& Smith, 2016; Nelson et al., 2009; Thornton et al., 2011). Climate change and variability could adversely affect Africa's food security in several ways (Boko et al., 2007; Kotir, 2011; Schlenker \& Lobell, 2010; Thornton et al., 2011; Yobom, 2020). First, climate extremes may influence the supply of food in Africa by reducing the area of viable arable land suitable for crop production (Amekudzi et al., 2015; Arnell, 2009; Owusu et al., 2021), leading to a surge in the prevalence and number of undernourished people. Second, a rise in temperature by $4{ }^{\circ} \mathrm{C}$ or more may have disastrous effects on many farmers' livelihoods in Africa (Thornton et al., 2011). Such a climate event may require higher productivity and more efficient distribution of resources to eradicate hunger across the continent. Brown et al. (2007) and Amekudzi et al. (2015) identified climate change as a new security threat to Africa. Further, Burke et al. (2009) attributed increased civil wars to climate change and detected a strong association between warmer years and past civil wars. Despite many studies conducted to examine the overall impact of climate change on food security in developing countries, evidence on the effects of climate change on food productivity remains inconclusive. 
This study adds to the ongoing discussions on climate change and food security by focussing on Africa. Further research in this area is crucial for several reasons. First, more than $20 \%$ of Africa's population is undernourished (FAO et al., 2019). Food availability remains a critical concern in Africa, given the rising population growth rates and poverty levels. Recent estimates show that 704 million people (9.2\%) of the world's population were subject to severe food insecurity in 2018 (FAO et al., 2019). The situation is most alarming in Africa, where severe food insecurity rose from 210.7 million to 277 million between 2014 and 2018, affecting 21.5\% of the population in 2018 (FAO et al., 2019). Food insecurity is on the increase in almost every sub-region of Africa. In 2018, Southern Africa had the highest prevalence of severe food insecurity (30.6\%), followed by Eastern Africa (25.9\%), Western Africa (17.6\%), and Northern Africa (8\%) (FAO et al., 2019). Bumb and Byrnes (1998) stated that cereals account for $60-70 \%$ of the average per capita calorie consumption, so they are periodically used as a proxy for food security. The quantities of cereals produced for food supply in countries are estimated in calories to reflect the amount of food everyone consumes (Bezuneh \& Yiheyis, 2014; Smith \& Haddad, 2001). Figure 1 displays the Pareto plot of average cereal production over the period 1970-2016 in 15 selected African countries with a history of food insecurity and food emergencies. On average, Nigeria produced 17,281,243 tonnes, followed by Egypt, producing 14,888,196 tonnes, with South Africa occupying the third position with 11,936,601 tonnes. Morocco came in fourth, producing 5,674,449 tonnes, followed closely by Kenya (3,084,558 tonnes), and Mali took sixth place with 2,828,047 tonnes. The Pareto plot of average cereal production shows that thirteen countries, including South Africa, cumulatively produced $50 \%$ of total cereal production by the selected African countries. In comparison, the remaining 50\% was generated proportionately by Nigeria and Egypt between 1970 and 2016.

Second, while the debate on food security continues, ongoing discussions concern the implications of frequent temperature variations, rainfall variability, and increased climatic events across African countries (Etana et al., 2021; Hulme et al., 2001; Nicholson et al., 2000; Nicholson, 2001; Owusu et al., 2021). Although Africa is considered a minor player in total global greenhouse gas emissions, generating less than $4 \%$ of the world's total (Oliver $\&$ Peters, 2020), the continent is susceptible to the adverse consequences of climate change variability (Boko et al., 2007; Lobell et al., 2011; Nakhooda et al., 2011; Sy, 2016). Prior evidence suggests that countries in Africa, especially those in sub-Saharan Africa

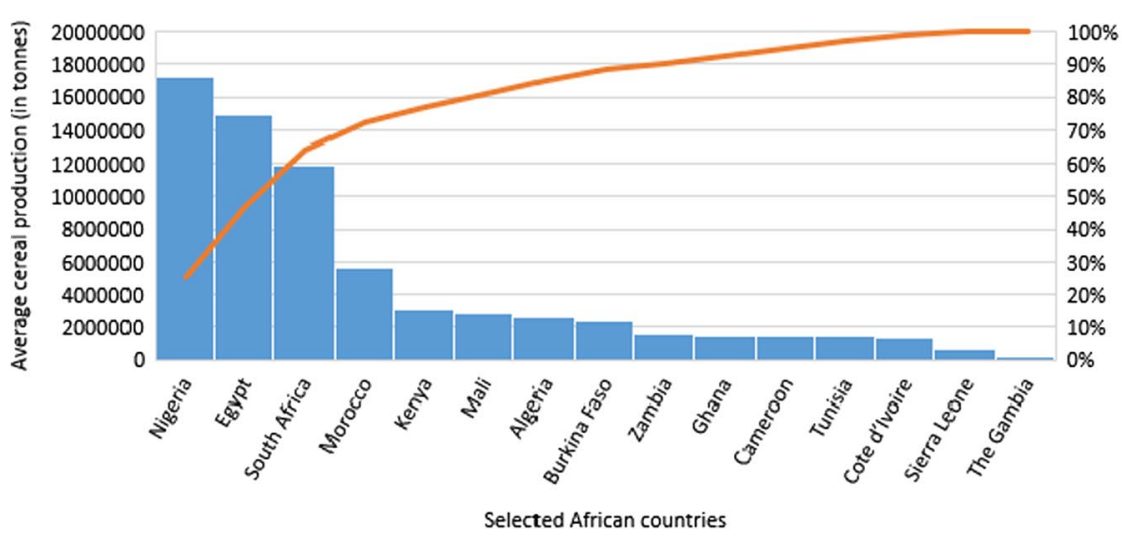

Fig. 1 Pareto plot of average cereal production in the selected African countries (1970-2016) 
(SSA), will experience an increase in temperature of $2-4{ }^{\circ} \mathrm{C}$ by 2100 , which is about 1.5 times higher than the expected mean increase in global temperature (Boko et al., 2007; Christensen et al., 2007). According to Easterling et al. (2007), a rise in temperature by $3{ }^{\circ} \mathrm{C}$ or more will cause food prices to increase by $40 \%$. A large proportion of the African population relies on rain-fed farming for their livelihood (Adhikari et al., 2015; Cooper et al., 2008; Muchuru \& Nhamo, 2019), so extreme climate variability poses a significant threat to food production (Boko et al., 2007; Etana et al., 2021; Lobell et al., 2011; Schlenker \& Lobell, 2010). Climate change and variability also raise food production costs, translating to high consumer prices (Berrera \& Hertel, 2021; Dadzie et al., 2021; FAO, 2008). Evidence shows that climate change could decrease agricultural output in SSA by $8 \%$ by 2080, compared with a decrease of about $4 \%$ in Asia (Shah et al., 2008). This negative effect of climate change will severely impair access to food, given that most economies in Africa are unable to finance food importation (Nathaniel et al., 2021; Shah et al., 2008). A decreased income for farmers in Africa resulting from reduced agricultural output will influence most households' capacity to buy food, even if it is available commercially.

Third, the susceptibility of the African continent to climate change requires desperate implementation of adaptation measures. Global attempts to curb climate change and its subsequent consequences have produced little benefit across Africa (Antwi-Agyei, 2012). Disasters, conflicts; ecosystem degradation; limited access to infrastructure, capital, markets, and technology; and climate change impacts currently inhibit food productivity across the continent (Boko et al., 2007; van den Bos Verma et al., 2020). Even though Africa commands approximately $60 \%$ of the world's uncultivated arable land, the continent contributes only $10 \%$ to world food production (Elbehri, 2015). The severity of the low productivity situation is exacerbated by a reduced workforce in commercial farming, combined with the expected rapid population growth (Ribaudo et al., 2011). Given Africa's constant struggle with hunger and famine, this raises concerns about the role of climate change in food security. The impact of climate change on agricultural production is a significant point of contention due to marginal environmental conditions in many countries in Africa, scarce resources for adaptation, and subsistence livelihoods (FAO, 2005). Thompson et al. (2010) stated that climate change is an imminent possibility for Africa, but there is no need for food insecurity. However, mitigating food insecurity in Africa requires the implementation of multi-country policy strategies.

Following the above discussion, we provided new empirical evidence on the impact of climate change on food security in Africa. In this study, our objective was to assess the impacts of climate change on food security in 15 selected African countries, namely Algeria, Burkina Faso, Cameroon, Cote d'Ivoire, Egypt, Ghana, Kenya, Mali, Morocco, Nigeria, Sierra Leone, South Africa, The Gambia, Tunisia, and Zambia. This study sought to answer three key questions. (1) What are the actual trends in climatic variability in these African countries? (2) What are the impacts of climate change on food security? (3) What is the causal relationship between climate change and food security?

\section{Econometric methodology}

\subsection{Model specification}

This study used climatic variables (i.e. temperature and rainfall) coupled with other explanatory variables (gross domestic product (GDP) per capita, population growth, and cultivated 
land under cereal production) to model the potential impacts of climate change on food security at country level. Thus, the food security model for a country is mathematically specified as follows:

$$
\text { FOSE }=f(\text { CULA, POP, GDPPC, TEMP, RAIN })
$$

where FOSE is food security. We used cereal availability as a proxy for FOSE in each country.CULA represents the cultivated area under cereal production, POP indicates population growth, GDPPC denotes GDP per capita, TEMP refers to average temperature, and RAIN signifies average rainfall.

We expressed Eq. (1) in an explicit and econometrics form as:

$$
\mathrm{LnFOSEL}_{i t}=\Omega_{0}+\beta_{1} \mathrm{LnCULA}_{i t}+\beta_{2} \mathrm{LnPOP}_{i t}+\beta_{3} \mathrm{LnGDPPC}_{i t}+\beta_{4} \operatorname{LnTEMP}_{i t}+\beta_{5} \operatorname{LnRAIN} \varepsilon_{i t}
$$

where $\beta_{i}$ represents the coefficient of the explanatory variables in the model to be estimated, $\Omega_{t}$ indicates the constant term, $\varepsilon_{t}$ refers to the error term, and Ln indicates a natural logarithm.

\subsection{Data characteristics}

In this study, we collated annual panel data on 15 countries across Africa for 1970-2016. We chose countries based on their history of food insecurity and food emergencies and their significant economic contribution to Africa's growth. The selected countries were Algeria, Burkina Faso, Cameroon, Cote d'Ivoire, Egypt, Ghana, Kenya, Mali, Morocco, Nigeria, Sierra Leone, South Africa, the Gambia, Tunisia, and Zambia. The data on population growth, GDP per capita, cultivated land under cereal production, temperature, and rainfall were extracted from the World Bank (2019). The data on food security were sourced from the FAO (2019). Rainfall and temperature were used as proxies for climate change. We measured food security, the dependent variable, by the total cereal availability in each country (Baye, 2016; Bezuneh \& Yiheyis, 2014; Byrnes \& Bumb, 1998; Smith \& Haddad, 2001). These variables were chosen for the present study following empirical literature and theoretical economic theory.

\subsection{Estimation strategies}

\subsubsection{Trend analysis of climatic variability}

To examine trends in climatic variability across Africa, we employed two nonparametric techniques: the Mann-Kendall test and Sen's slope estimator (Pickson et al., 2020). These tests ascertain trends in climatic variability and establish the corresponding magnitude. The Mann-Kendall test (Kendall, 1975; Mann, 1945) is a nonparametric technique employed to determine time-series trends. The Mann-Kendall test empirically verifies the null hypothesis that 'there is no trend' or the alternative hypothesis that 'there is a decreasing or rising monotonic trend'. The null hypothesis assumes that observations $\left(C_{i}\right)$ are independently ordered at random. Therefore, the statistic $(S)$ of the Mann-Kendall test is estimated as:

$$
S=\sum_{k=1}^{n-1} \sum_{j=k+1}^{n} \operatorname{sgn}\left(C_{j}-C_{k}\right)
$$


where $C_{j}$ and $C_{k}$ indicate the data scores in time-series $j$ and $k(j>k)$, correspondingly. The $\operatorname{sign}\left(C_{j}-C_{k}\right)$ is the sgn function as:

$$
\begin{aligned}
& \operatorname{sgn}\left(C_{j}-C_{k}\right)=\begin{array}{ll}
1 & \text { if } C_{j}-C_{k}>0 \\
0 & \text { if } C_{j}-C_{k}=0
\end{array} \\
& -1 \text { if } C_{j}-C_{k}<0
\end{aligned}
$$

The $p$ value is computed with the test statistic $(S)$ and the sample size $(n)$ to determine whether the trend is statistically significant. The variance of $S$ is estimated as follows:

$$
\operatorname{VAR}(S)=\frac{1}{18}\left[n(n-1)(2 n+5)-\sum_{i=1}^{m} t_{i}\left(t_{i}-1\right)\left(2 t_{i}+5\right)\right]
$$

where $m$ signifies the number of tied groups, $n$ represents the number of data points, and $i$ represents the number of data points in the $i$ th group. The standard normal test statistic $Z$ is computed as:

$$
Z= \begin{cases}\frac{S-1}{\sqrt{\operatorname{VAR}(S)}} & \text { if } S>0 \\ 0 & \text { if } S=0 \\ \frac{S+1}{\sqrt{\operatorname{VAR}(S)}} & \text { if } S<0\end{cases}
$$

A positive $Z$ statistic indicates an upward or increasing trend, whereas a negative $Z$ statistic suggests a downward or decreasing trend. Our testing trends are established at the 5\% significance level $(\alpha=0.05)$. The null hypothesis that 'there is no trend' is refuted when the absolute value of the computed $Z$ statistic is greater than the critical value of $Z_{1-\alpha / 2}$ (i.e. $Z_{1-\alpha / 2}=1.96$ ), which indicates the existence of a trend. Nonetheless, the null hypothesis is accepted when the absolute value of the computed $Z$ statistic is lower than the critical value of $Z_{1-\alpha / 2}=1.96$ ), therefore implying no evidence of a trend (Pickson et al., 2020). The empirical literature shows that the Mann-Kendall test can ascertain the significance of trends in climatic variables (Douglas et al., 2000; Gocic \& Trajkovic, 2013; Modarres \& Silva, 2007; Partal \& Kahya, 2006; Pickson et al., 2020; Tabari \& Marofi, 2011; Tabari et al., 2011b; Yue et al., 2002).

Unlike the Mann-Kendall test, we used Sen's slope estimator (Sen, 1968) to compute the exact slope of a prevailing trend as it changes over time. Sen's slope estimator applies a simple nonparametric technique to a linear model $g(t)$, which is specified as:

$$
g(t)=Q_{t}+b
$$

where $t$ indicates time, $b$ is a constant, and $Q$ represents the slope. The slope $\left(Q_{i}\right)$ of the trend in the sample of $N$ data pairs is calculated to deduce the magnitude of the direction as follows:

$$
Q_{i}=\frac{C_{j}-C_{k}}{j-k} \text { for } i=1,2,3 \ldots \ldots N, \text { and } j>k .
$$

where $C_{j}$ and $C_{k}$ are the data values at time $j$ and $k$, respectively. The $N$ values of $Q_{i}$ are rated from the lowest to the highest, and Sen's slope estimator is calculated as: 


$$
Q_{\text {med }}= \begin{cases}T_{[(N+1) / 2]}, & \text { if } N \text { is odd } \\ \frac{1}{2}\left(T_{[N / 2]}+T_{[(N+2) / 2]}\right), & \text { if } N \text { is even }\end{cases}
$$

The $Q_{\text {med }}$ value is calculated according to a normal distribution. The sign of the $\left(Q_{\text {med }}\right)$ value reflects the data trend. A negative $Q_{i}$ value indicates a downward trend, while a positive slope value $\left(Q_{\text {med }}\right)$ suggests an upward trend in the data. In this study, a confidence interval of $95 \%$ was used to indicate whether Sen's slope estimator is statistically different from zero. In the existing literature, Sen's slope estimator is mainly used to determine the magnitude of trends in climatic variables (ElNesr et al., 2010; Gocic \& Trajkovic, 2013; Partal \& Kahya, 2006; Pickson et al., 2020; Tabari \& Marofi, 2011; Tabari et al., 2011a; Yue \& Hashino, 2003; Yunling \& Yiping, 2005).

\subsubsection{Panel unit root tests}

We used unit root tests to examine the stationarity properties of variables (Choi, 2001; Im et al., 2003; Levin et al., 2002; Maddala \& Wu, 1999). Levin et al.'s (2002) unit root test allows for homogeneity in the autoregressive coefficients and suggests the existence or absence of a unit root problem. Although the Im-Pesaran-Shin (IPS) unit root test is less rigorous, it is more appropriate than the LLC unit root test as it accounts for heterogeneity in autoregressive coefficients. For robustness, we also applied the augmented Dickey-Fuller (ADF) unit root test developed by Maddala and Wu (1999) and Choi (2001). The ADF test is a Fisher-type test that combines $p$ values obtained from each cross-section's stationarity tests. The ADF test is more efficient than the IPS test as it is responsive to the selected lag length in regressions. In this study, each stationarity test was performed with a deterministic intercept and trend.

\subsubsection{Pooled mean group estimation approach}

The study used the pooled mean group (PMG) estimation approach for dynamic heterogeneous panels (Pesaran et al., 1999). One of the merits of the PMG estimation technique compared with other heterogeneous co-integration methods is that it limits the long-run coefficients to be homogeneous cross-sections. This approach was appropriate for this study because of the selected countries' food insecurity history, comparable economic features, related political systems, and similar regional climatic characteristics, which affect the long-run coefficient in identical circumstances. The PMG estimator is not akin to the mean group (MG) estimator, which allows long-run coefficients to vary among selected countries (Kim et al., 2010; Ofori-Abebrese \& Pickson, 2018; Pesaran et al., 1999). However, both PMG and MG estimators require short-run coefficients to be heterogeneous among specified countries.

Another advantage of the PMG estimator is that it is applicable irrespective of whether the variables are integrated of order zero or one [i.e. $I(0)$ or $I(1)$ ] (Pesaran et al., 2001). Further, inferences of long-run and short-run causality can be made with the PMG estimator even if the existence of co-integration is not systematically determined. Thus, we deployed the PMG technique to assess the long-run and short-run implications of climate change for food security and a heterogeneous dynamic issue among Africa's selected countries. The PMG method of estimation can be specified as an unrestricted autoregressive distributed lag (ARDL) model: 


$$
Y_{i t}=\sum_{j=1}^{m} \theta_{i j}\left(Y_{i}\right)_{t-j}+\sum_{j=0}^{n} \beta_{i j}\left(Z_{i}\right)_{t-j}+\mu_{i}+\varepsilon_{i t}
$$

where $Y_{i t}$ represents food security which is the dependent variable, whereas $Z_{i t}$ is a vector of regressors such as GDP per capita, population growth, cultivated area, temperature, and rainfall for each country. Moreover, $\theta_{i j}$ denotes scalars, $\beta_{i j}$ represents the coefficient vectors, $\mu_{i}$ shows the group-specific effect, and $\varepsilon_{i t}$ is a white-noise error term with zero mean and constant variance.

Similarly, Eq. (10) can be rewritten as an error correction model:

$$
\Delta Y_{i t}=\phi_{i}\left(Y_{i, t-1}-\lambda_{i} Z_{t-1}\right)+\sum_{j=1}^{m-1} \theta_{i j} \Delta\left(Y_{i}\right)_{t-j}+\sum_{j=0}^{n-1} \beta_{i j} \Delta\left(Z_{i}\right)_{t-j}+\mu_{i}+\varepsilon_{i t}
$$

where $\lambda_{i}$ represents the long-run coefficients, which are assumed to be homogeneous among the selected countries, $\phi_{i}$ shows the error correction term coefficient, which is the speed of adjustment to long-run equilibrium in the event of any shock to the system. $\beta_{i}$ indicates the short-run coefficients, which are heterogeneous across the selected countries, $\mu_{i}$ represents the country-specific effect, and $\varepsilon_{i t}$ denotes the error term with differing variance across the selected countries. According to Pesaran et al. (1999), results obtained from the PMG estimation are 'consistent and normally distributed asymptotically'.

\subsubsection{Dumitrescu-Hurlin panel causality test}

We employed the Dumitrescu-Hurlin causality test (Dumitrescu \& Hurlin, 2012) to ascertain the causal association between population growth, GDP per capita, cultivated area, temperature, rainfall, and food security. A better understanding of causality among variables helps policymakers implement appropriate policies to ensure sustainable food security. The Dumitrescu-Hurlin causality test presumes that all the coefficients differ across cross-sections. However, Monte Carlo simulations suggest that this test can generate strong outcomes even in the presence of cross-sectional dependency (Dogan \& Bulbul, 2017). The Dumitrescu-Hurlin causality test applies when $T>N$ and $T<N$ and it can also be used on both balanced and heterogeneous panels. Dumitrescu and Hurlin (2012) considered the ensuing linear model for the panel causality test:

$$
y_{i t}=\Omega_{i}+\sum_{n=1}^{N} \rho_{i}^{(n)} y_{i, t-n}+\sum_{n=1}^{N} \theta_{i}^{(n)} x_{i, t-n}+\mu_{i, t}
$$

where $\rho_{i}^{(n)}$ stands for the autoregressive parameter, $\theta_{i}^{(n)}$ represents the coefficient slope that differentiates across cross-sections, $\Omega_{i}$ connotes the constant term, and $N$ indicates the lag length, which is presumed to be the same for all the cross-sections where the panel is balanced.

The following expressions are the null and alternative hypotheses for testing the panel Granger causality:

$$
\begin{array}{ll}
H_{0}=\theta_{i}=0 & \forall_{i}=1, \ldots, N \\
H_{1}=\theta_{i}=0 & \forall_{i}=1, \ldots, N \\
H_{1}=\theta_{i} \neq 0 & \forall_{i}=N+1, N+2, \ldots, N
\end{array}
$$


More precisely, the null hypothesis asserts that no homogeneous causality exists for all cross-sections. In contrast, the alternative proposition suggests evidence of at least one causal association in the panel data.

\section{Empirical results and discussion}

\subsection{Trend analysis of climatic variability}

The present study established significant positive trends in temperature in selected African countries between 1970 and 2015 (see Table 1). In Algeria, Egypt, and Tunisia, the average annual temperature exhibited significant and increasing trends with corresponding $Z$ values of $2.14,2.14$, and 2.34. In addition, except in January and February, the average temperature in Algeria, Egypt, and Tunisia displayed a significant positive trend across the months. Moreover, the annual temperature increased significantly in Cameroon, Cote d'Ivoire, and Ghana, with $Z$ values of 3.08, 3.45, and 2.75 , respectively. We detected a significant upward trend in temperature on a monthly scale; however, there were no notable temperature trends detected for January in Cameroon, Cote d'Ivoire, or Ghana. Monthly and annual average temperature data exhibited a significant upward trend in Kenya and the Gambia. Similarly, the average annual temperatures in Burkina Faso, Mali, Morocco, Nigeria, Sierra Leone, South Africa, and Zambia showed significant rising trends, given $Z$ values of 2.67, 2.14, 2.22, 2.30, $2.51,2.63$, and 2.46 , which are higher than $Z_{0.05 / 2}=1.96$. The results again indicated a significant positive trend in monthly temperature except for January and August in Burkina Faso; January, February, August, and September in Mali; January, February, May, August, September, and November in Morocco; January in Nigeria; January and December in Sierra Leone; April, June, and November in South Africa; and April in Zambia.

Analyses of monthly and annual rainfall patterns may be considered crucial as most African farmers depend heavily on rainfall for agricultural production. Table 2 provides monthly and annual rainfall patterns from 1970 to 2015, based on both the Mann-Kendall test and Sen's slope estimator. According to the findings, only Burkina Faso, Mali, and the Gambia exhibited increasing annual rainfall rates, given $Z$ values of $2.23,2.59$, and 2.06, respectively. However, we found no significant trend in annual average rainfall in Algeria, Cameroon, Egypt, Ghana, Kenya, Morocco, Nigeria, Sierra Leone, South Africa, Tunisia, and Zambia, with $Z$ values of $0.21,-0.98,0.98,-0.97$, $0.28,0.51,-0.44,1.08,1.27,-1.38,-0.38$, and 0.08 , respectively, which are lower than $Z_{0.05 / 2}=1.96$. Moreover, there were no significant trends in monthly average rainfall in South Africa, Tunisia, and Zambia. In Cameroon and Kenya, the results indicated a significant decreasing rainfall trend in July, whereas Algeria and Sierra Leone observed a positive rainfall pattern in August. In addition, the study found substantial changing patterns in rainfall in May, August, and October for Burkina Faso; October and November for Cote d'Ivoire; June and August for Egypt; October and November for Ghana; July, September, and October for Nigeria; August and September for Morocco; January, February, August, and October for Mali, and August, September, and October for the Gambia. 


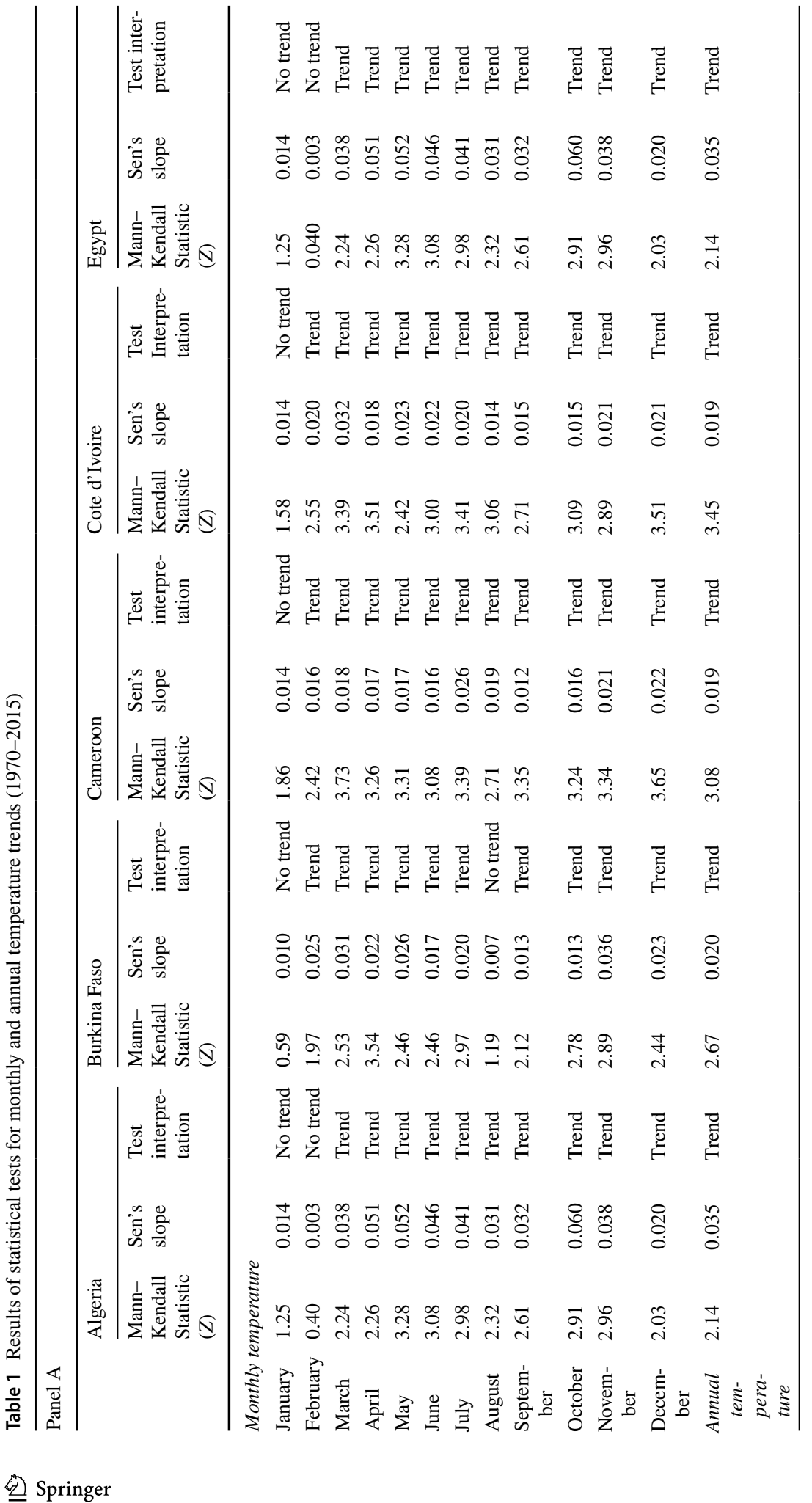




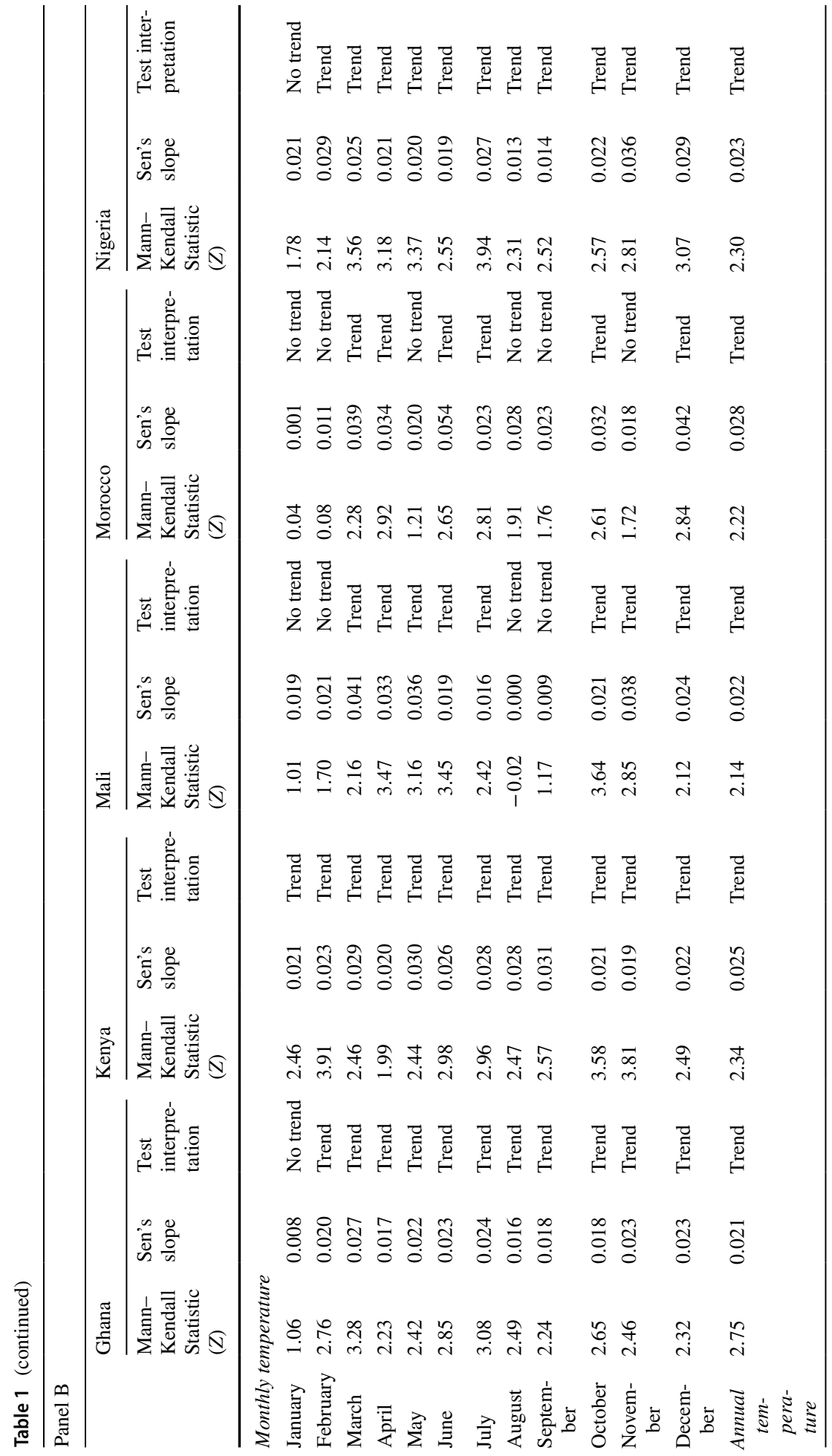




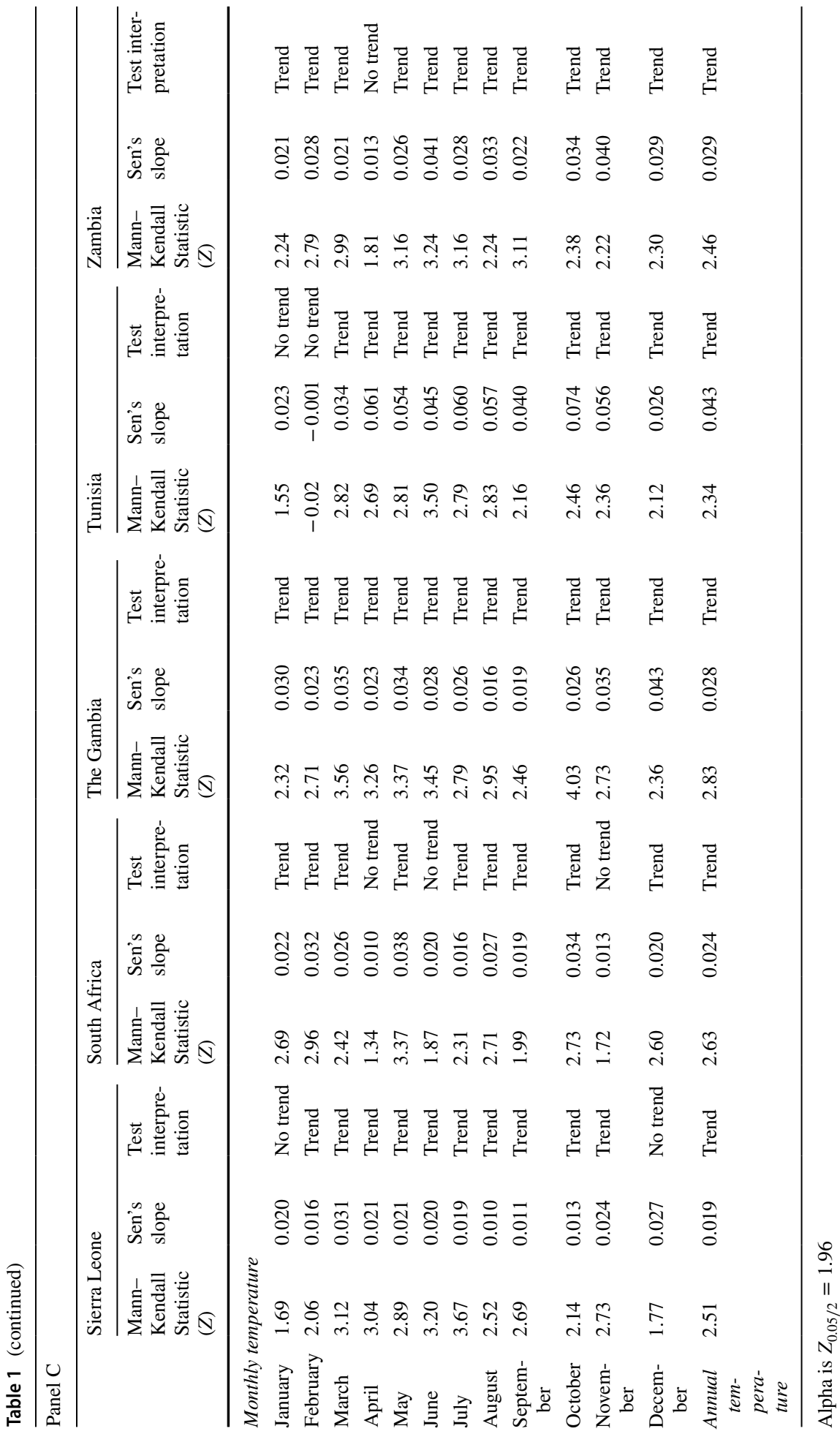




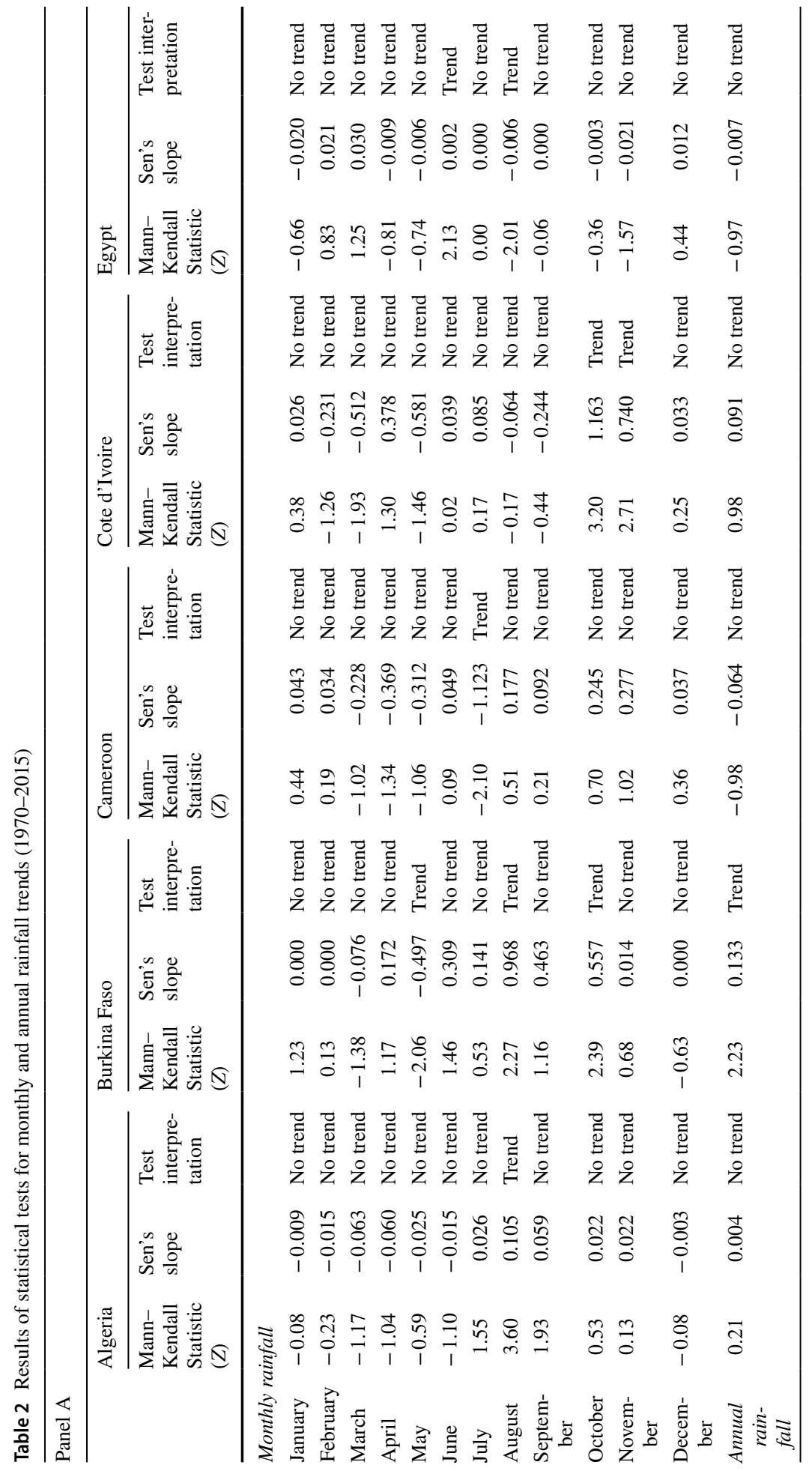




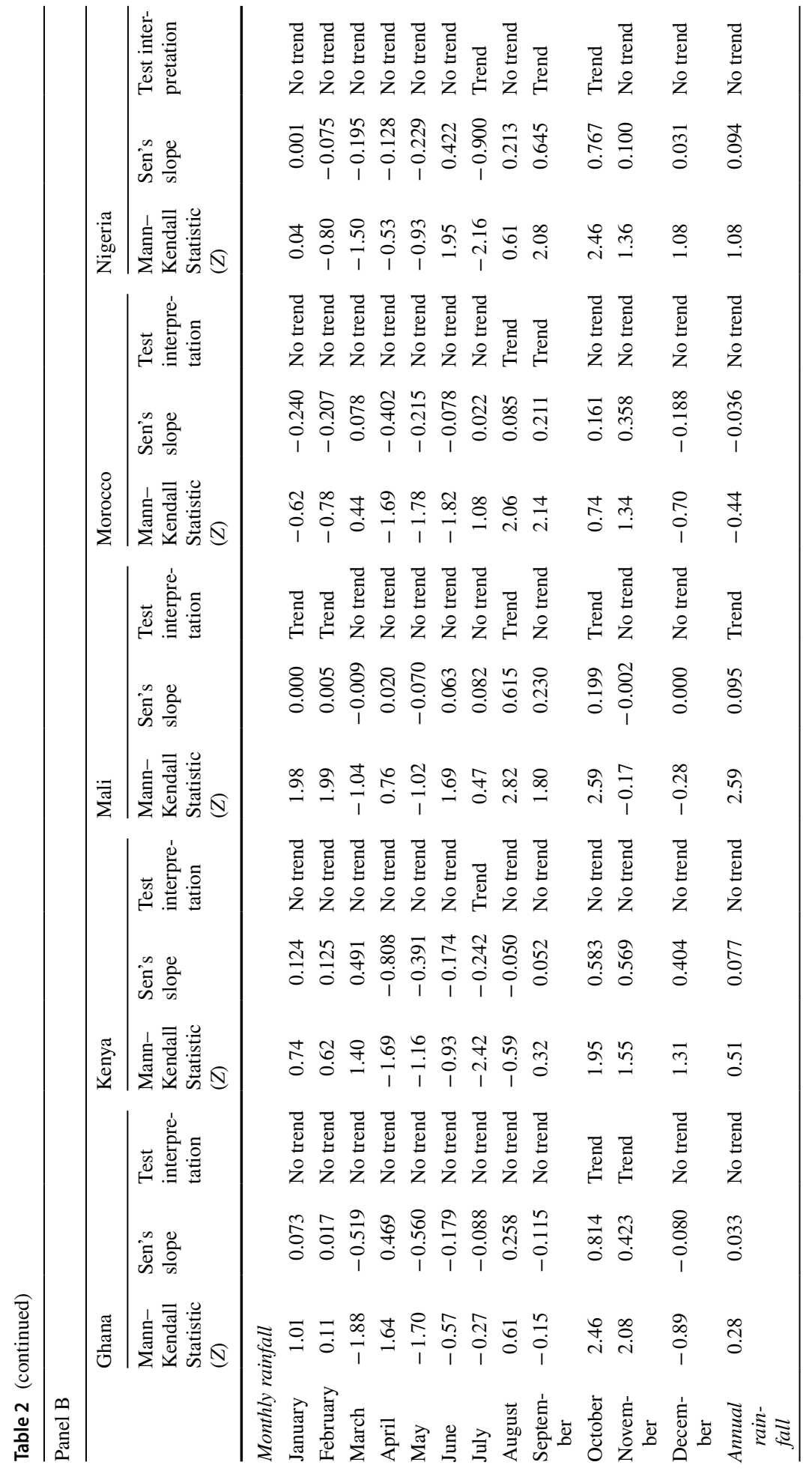




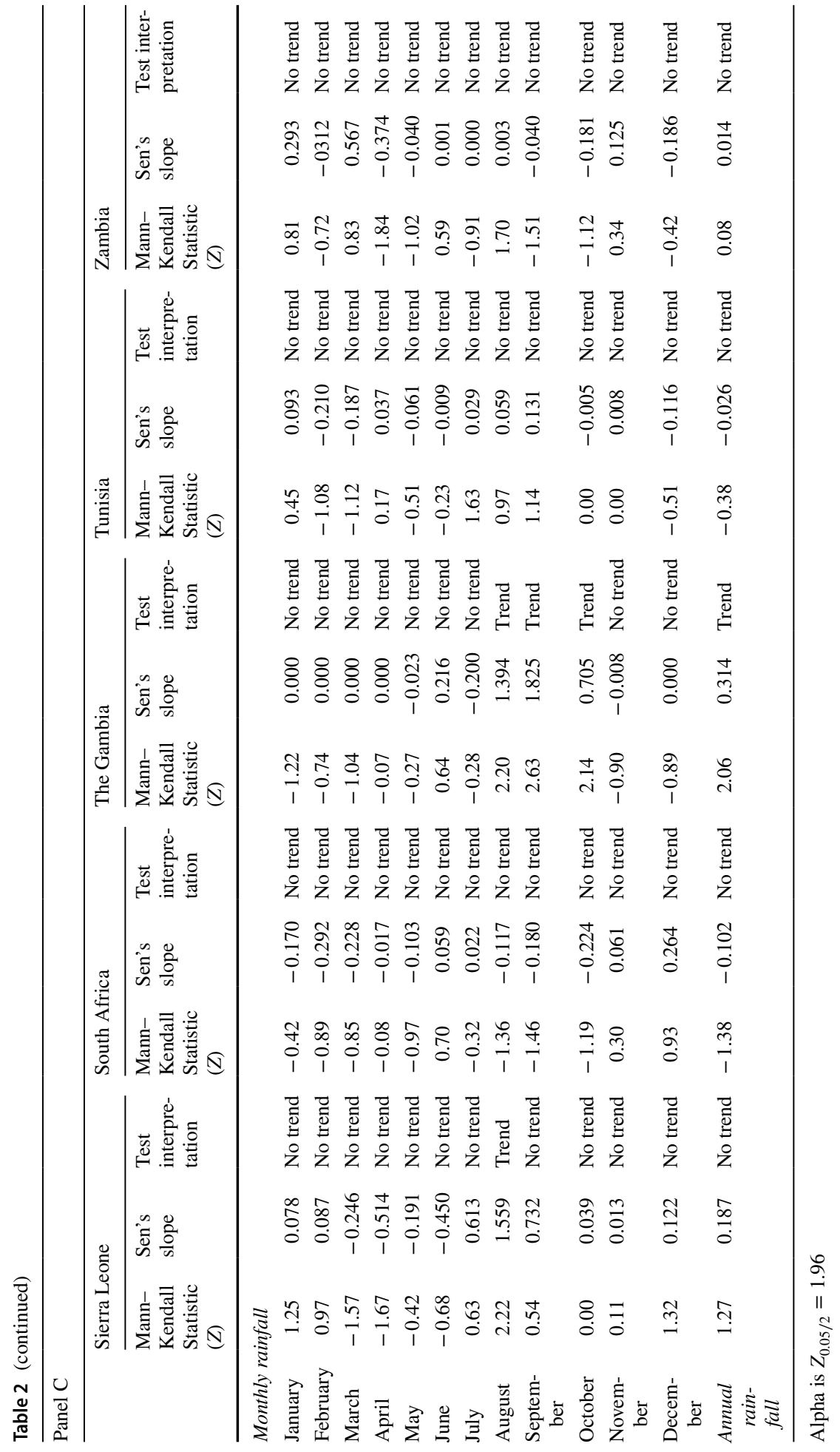




\subsection{Results of the stationarity tests}

The study used the LLC, IPS, and ADF stationarity tests. The results of these panel unit root tests revealed that cultivated area, population growth, temperature, rainfall, and food security were stationary at their levels, thereby being integrated of order zero [i.e. $I(0)$ ] (see Table 3). However, GDP per capita was stationary at its first difference, suggesting that GDP per capita is integrated of order one (i.e. $I(1)$ ). These outcomes ensure the suitability of applying the panel ARDL approach for investigating climate change implications for Africa's food security.

\subsection{Results of the long-run relationship}

This section presents the empirical results for examining the effects of precipitation and temperature, including critical control variables, on Africa's food security. Evidence from Hausman test statistics (see Table 4) indicates the acceptance of the null hypothesis of homogeneous long-run estimated coefficients when analysed at a $95 \%$ confidence interval. This finding implies that estimates from the PMG technique are more consistent and precise than the MG computations. Thus, the PMG approach is more suitable for the present study as it accounts for short-run heterogeneity in estimations (Pesaran et al., 1999). Therefore, our discussion focused on the PMG results of the long-run relationship (see Table 4). We later deployed the ARDL approach for time-series datasets to examine the long-run heterogeneous impacts of climate change on selected African countries' food security (see Table 4).

The positive and significant coefficient of LnCULA suggests that cultivated land under cereal production has improved food security in Africa. Out of the 15 selected countries, 14 reported a significant direct association between cropped areas and food security in the long run-Algeria (1.349), Burkina Faso (0.922), Cameroon (0.617), Egypt (0.693), Ghana (2.094), Kenya (1.006), Mali (0.290), Morocco (2.299), Nigeria (0.513), Sierra Leone (1.093), South Africa (0.946), the Gambia (0.897), Tunisia (0.559), and Zambia (0.757). Indeed, most African economies are driven by the agricultural sector. Nevertheless, low agricultural production in the region results from

Table 3 Results of the panel unit root tests

\begin{tabular}{lccc}
\hline Deterministic component: individual intercept and trend & \\
\hline Variables & Levin, Lin, \& Chu (LLC) & Im-Pesaran-Shin (IPS) & $\begin{array}{l}\text { Augmented } \\
\text { Dickey-Fuller } \\
\text { (ADF) }\end{array}$ \\
\hline LnCULA & $-1.291^{*}$ & & $-2.948^{* * *}$ \\
LnGDPPC & 1.017 & $-3.218^{* * *}$ & 2.459 \\
$\Delta$ LnGDPPC & $-6.766^{* * *}$ & 2.418 & $-9.988^{* * *}$ \\
LnPOP & $-20.890^{* * *}$ & $-11.052^{* * *}$ & $-14.356^{* * * *}$ \\
LnTEMP & $-10.393^{* * *}$ & $-17.757^{* * *}$ & $-10.048^{* * *}$ \\
LnRAIN & $-9.359^{* * *}$ & $-10.871^{* * *}$ & $-10.300^{* * *}$ \\
LnFOSE & $-1.588^{* * *}$ & $-11.306^{* * *}$ & $-14.356^{* * *}$ \\
\hline
\end{tabular}

$* * * *, * *$, and $*$ indicate $1 \%, 5 \%$, and $10 \%$ levels of significance, respectively. Also, $\Delta$ denotes the first difference operator 


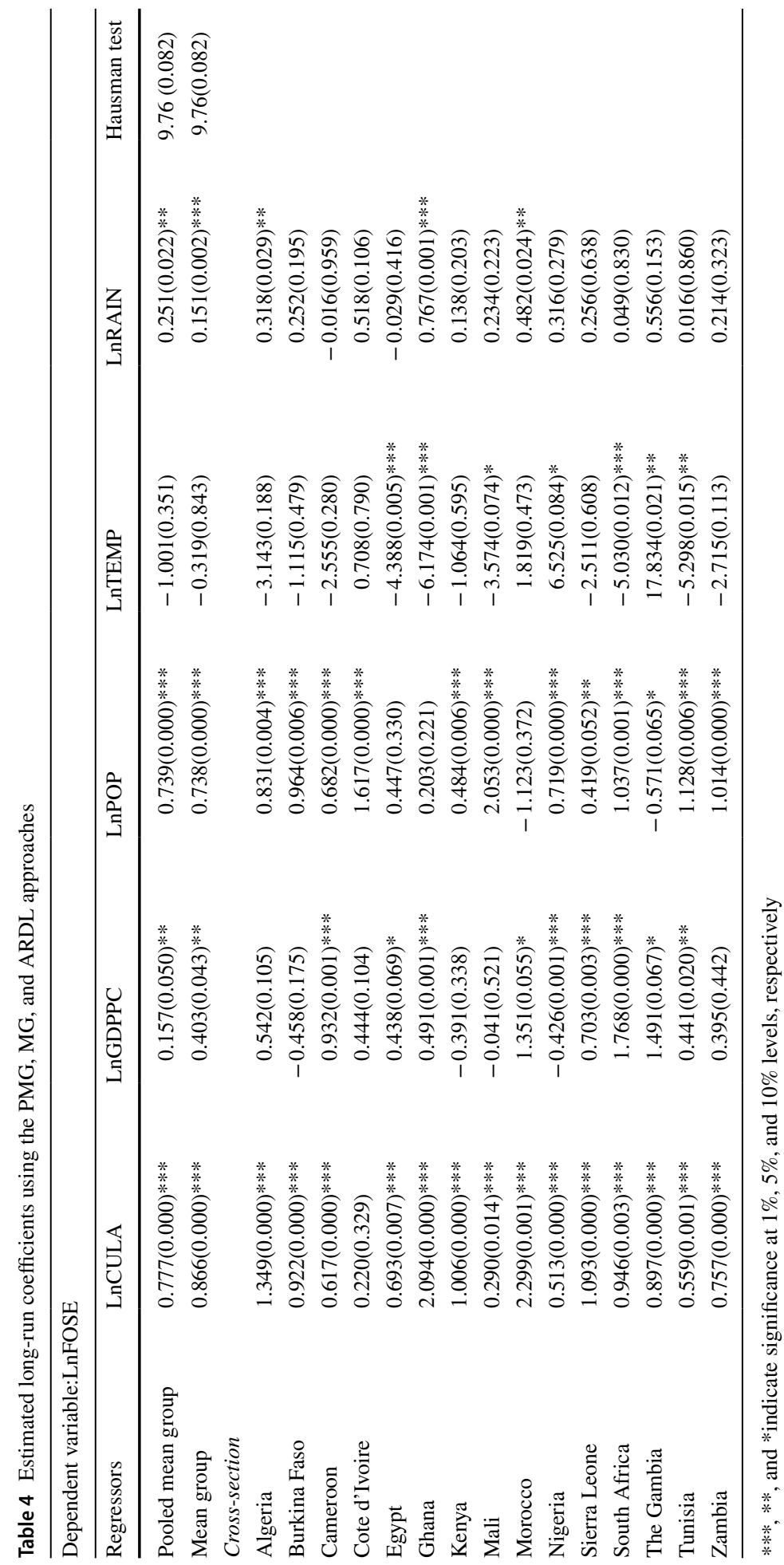


inadequate farmland access, especially for rural communities. In line with Dogliotti et al. (2014), and Bezuneh and Yiheyis (2014), our findings suggest that the African region will benefit from increased agricultural production by providing greater access to arable land for cereal production to meet consumption demands.

LnGDPPC entered the regression with a significant positive coefficient, suggesting that per capita income supports food security. The long-run impact of GDP per capita on food security at the regional level reflects its effects at the country level. Of the 15 selected countries, GDP per capita directly influenced food security in 8 countries in the long run-Cameroon (0.932), Egypt (0.438), Ghana (0.491), Morocco (1.351), Sierra Leone (0.703), South Africa (1.768), the Gambia (1.491), and Tunisia (0.441). Factors on both the demand and supply sides can explain this outcome. From the demand side, analysis of the income-consumption-production model in Africa suggests that the growth in GDP per capita significantly induces the region's demand for agricultural output. However, as the proportion of consumer spending on food declines with income growth (Fukase \& Martin, 2017), Africa's food demand will increase if rising income drives consumers' purchasing power and food security. From the supply side, both productivity and income growth strongly influence food production.

In some regions, rapid population growth and poverty threaten food security (Asian Development Bank, 2012; Faisal \& Parveen, 2004; Yang \& Hanson, 2009). However, our evidence indicates that population growth (LnPOP) exerts a positive and significant influence on food security in Africa (see Table 4). At the country level, our results suggest that rising population growth positively influences food security in Algeria (0.831), Burkina Faso (0.964), Cameroon (0.682), Cote d'Ivoire (1.617), Kenya (0.484), Mali (2.053), Nigeria (0.719), Sierra Leone (0.419), South Africa (1.037), Tunisia (1.128), and Zambia (1.014) in the long run. Thus, the rise in population growth does not impede efforts to promote food security in Africa. The reason is that the current policies adopted by various governments in Africa to promote financial inclusion, coupled with improved disease-resistant varieties of staple crops and reduced land degradation, have imposed favourable impacts on food production. These interventions have allowed food production to remain slightly ahead of population growth.

Regarding critical variables, temperature (LnTEMP) did not appear to significantly influence food security when examined at standard $1 \%$ to $10 \%$ significance levels. The study found that the long-run impact of temperature on food security at the regional level was akin to its effects at the country level. Our findings indicate that temperature has a negligible influence on food security in many countries. However, it has either a negative or positive impact on food security in some countries. For instance, the results exhibit a significant negative relationship between temperature and food security in the long term-Egypt (-4.388), Ghana (-6.174), Mali (-3.574), South Africa (-5.030), and Tunisia (-5.298). On the other hands, the temperature has a positive impact on food security in Nigeria (6.525) and the Gambia (17.834) in the long run.

In contrast to temperature, rainfall patterns have a substantial impact on Africa's food security. Specifically, the estimated coefficient of rainfall (LnRAIN) was positive and statistically significant at the $1 \%$ level in the long run. The magnitude and significance of precipitation's effect, on the other hands, differ across countries. As most African countries depend on rainfall for farming activities, food security and productivity may be particularly vulnerable to reduced rainfall conditions (Akinbile et al., 2020; Demeke et al., 2011; Tankari, 2020). Recent studies by Meheretu (2020) and Wong et al. (2020) postulated that unpredicted rainfall patterns and regular drought occurrences have a detrimental effect on food production, thus reflecting how growing climate instability 
profoundly impacts food insecurity, which is more pronounced in rural areas with less irrigation for food production.

\subsection{Short-run relationship results}

Table 5 shows the computations of the error correction model performed using the PMG approach. In the short term, the heterogeneity of the concerned variables proposed by the PMG technique helped in conducting cross-sectional estimations to infer the most probable economic policy consequences. First, analysis of $\mathrm{ECT}_{t-1}$ estimates suggested a rejection of the null hypothesis of no long-run relationship among the variables. We found the estimated coefficient of $\mathrm{ECT}_{t-1}$ to be within the range of -0.271 in Nigeria to -0.945 in Tunisia. Nigeria's food security disruptions caused by cultivated areas, population growth, GDP per capita and climatic variables were corrected within four years (1/0.271). Thus, Nigeria requires four years for the disturbances in her food security conditions to die out. At the same time, Cote d'Ivoire requires three years $(1 / 0.353)$ to restore equilibrium after adverse shocks to food security. The effects of shocks to cultivated land, population growth, GDP per capita, and climatic variables on food security in countries such as Cameroon and Ghana were corrected with adjustment periods of three years (1/0.401) and two years (1/0.458), respectively. Nevertheless, Tunisia's food security disturbances were corrected within a year (1/0.945), indicating stable food security in Tunisia compared with other countries.

From the short-run results, the study revealed that except for Mali, Tunisia, and Zambia-where the estimated coefficient of $\Delta$ LnCULA was insignificant-the effect of cultivated land under cereal production on food security was positive and significant. Thus, the evidence showed an increase in $\triangle$ LnCULA to positively influence food security in Egypt, Morocco, South Africa, and the Gambia, with elasticity values of 1.052, 1.028, 1.202 , and 1.003, respectively. The short-run effect of GDP per capita did not deviate from the long-run estimates. However, GDP per capita significantly induced food security in the short run in five countries, namely Cameroon $(0.356$ at $10 \%$ significance level), Ghana (1.036 at 1\% significance level), Morocco (6.570 at 1\% significance level), the Gambia (1.317 at $1 \%$ significance level), and Zambia (0.988 at $1 \%$ significance level). For these economies, the estimated coefficient of $\triangle$ LnGDPPC suggests that food security is susceptible to changes in income per capita in Ghana, Morocco, the Gambia, and Zambia, but it is less pronounced in Cameroon.

Further, the short-run impact of $\triangle \mathrm{LnPOP}$ on food security varied substantially among countries. For example, while the results indicated that population growth had a negative and significant effect on food security in Algeria, Cameroon, and South Africa, there was a positive relationship between population growth and food security in Burkina Faso and Kenya. Regarding the critical climate variables under consideration, the short-run effect of $\Delta$ LnTEMP for the pooled countries was negative $(-0.0563)$ and significant. When examined across countries, the study unearthed that only in Egypt did $\triangle$ LnTEM adversely affect food security $(-0.708$ at $1 \%$ significance level). Conversely, and in line with the long-run estimations, $\Delta$ LnRAIN significantly induced food security in the short-run $(0.113$ at $1 \%$ significance level). The study reported a similar effect in countries such as Cote d'Ivoire (0.188 at $10 \%$ significance level), Ghana $(0.285$ at $5 \%$ significance level), Mali (0.442 at $1 \%$ significance level), and the Gambia (0.226 at $1 \%$ significance level). 


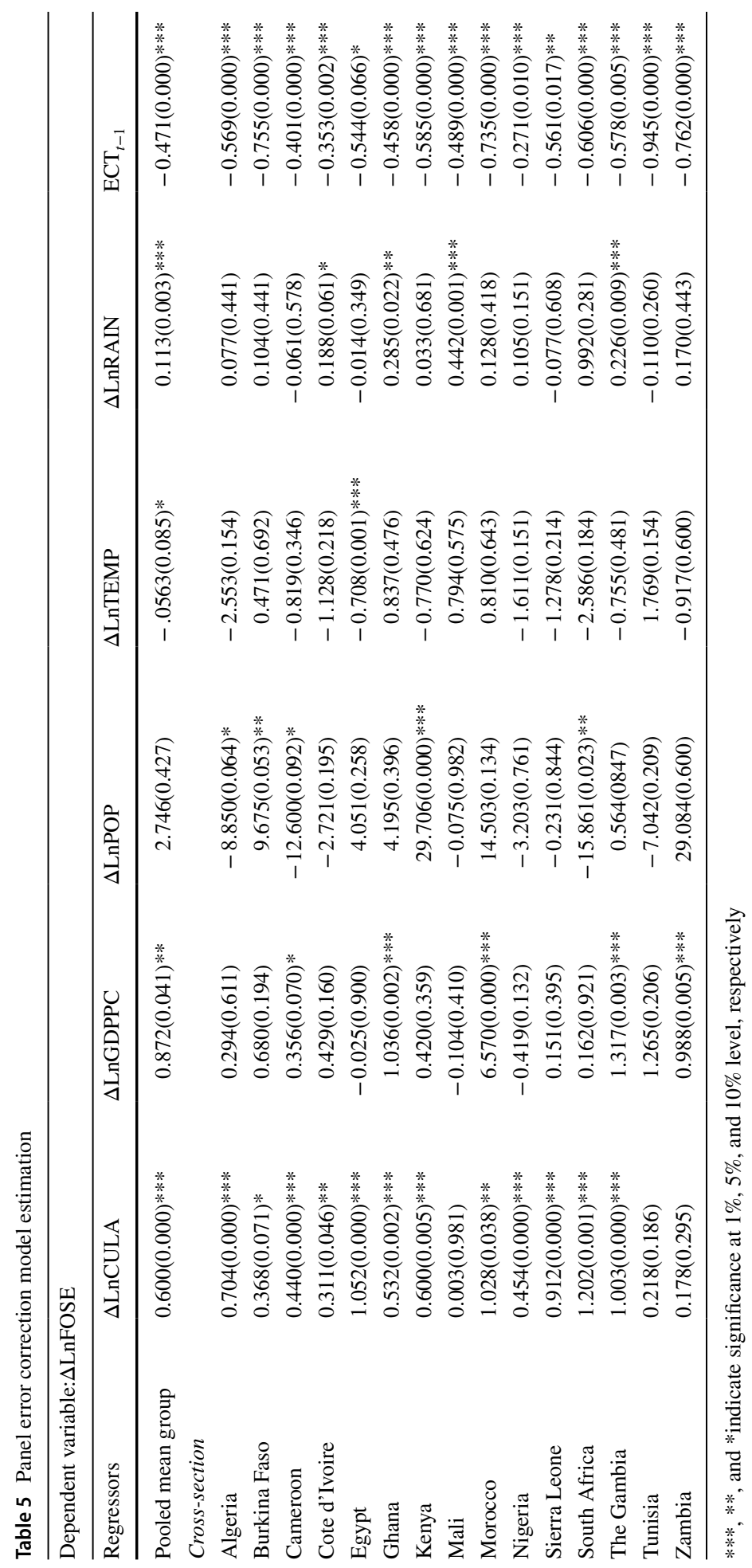




\subsection{Dumitrescu-Hurlin panel causality test results}

The study further employed the Dumitrescu-Hurlin panel causality test to assess the direction of causality between the key variables and food security (see Table 6).

The empirical findings indicated that the null hypothesis that cultivated areas, GDP per capita, and population growth do not homogeneously cause food security was rejected at a $1 \%$ threshold (see Table 6). The results indicated that variations in cultivated areas, GDP per capita, and population growth in African countries significantly influenced food security. Additionally, the results disproved the null hypothesis that food security does not homogeneously cause changes in cultivated areas, GDP per capita, and population growth. The findings infer that food security has a causal effect on cultivated areas, GDP per capita, and population growth in the selected African countries. Thus, the empirical findings imply a bidirectional causality between cultivated areas and food security, GDP per capita and food security, and population growth and food security.

Regarding climatic conditions, the null hypothesis that temperature does not homogeneously cause food security was refused at a $1 \%$ threshold. Similarly, the study discovered that fluctuations in food security significantly led to changes in temperatures across African countries. The results, therefore, imply a bidirectional causality between temperature and food security. Moreover, at a $1 \%$ threshold, the null hypothesis that rainfall does not homogeneously affect food security was rejected. This finding implies that rainfall patterns across the countries better predict variations in food security. However, this study established that variations in food security do not homogeneously cause changes in rainfall patterns across countries. Therefore, given the empirical evidence, there is a unidirectional causality running from rainfall to food security in Africa.

\section{Conclusions and policy implications}

Extreme weather conditions are among the key factors influencing food security in Africa. Temperature variations have imposed numerous repercussions on the continent's food production as most African economies rely on rainfall for agricultural production. Given the lack of consensus about the actual impact of climate change on food security in Africa,

Table 6 Results of the Dumitrescu-Hurlin panel causality test

\begin{tabular}{llll}
\hline Null Hypothesis: & W-Statistic & Probability & Direction of causality \\
\hline LNFOSE does not homogeneously cause LNCULA & $5.140^{* * *}$ & 0.000 & Bidirectional causality \\
LNCULA does not homogeneously cause LNFOSE & $4.014 * * *$ & 0.001 & \\
LNGDPPC does not homogeneously cause LNFOSE & $3.608^{* * *}$ & 0.009 & Bidirectional causality \\
LNFOSE does not homogeneously cause LNGDPPC & $3.588^{* * *}$ & 0.010 & \\
LNPOP does not homogeneously cause LNFOSE & $9.118^{* * *}$ & 0.000 & Bidirectional causality \\
LNFOSE does not homogeneously cause LNPOP & $6.648^{* * *}$ & 0.000 & \\
LNRAIN does not homogeneously cause LNFOSE & $4.403 * * *$ & 0.000 & Unidirectional causality \\
LNFOSE does not homogeneously cause LNRAIN & 2.934 & 0.148 & \\
LNTEMP does not homogeneously cause LNFOSE & $6.846^{* * *}$ & 0.002 & Bidirectional causality \\
LNFOSE does not homogeneously cause LNTEMP & $7.330^{* * *}$ & 0.0000 & \\
\hline
\end{tabular}

***Indicates rejection of the null hypothesis at a $1 \%$ level of significance 
this study examined the roles of rainfall and temperature patterns in food security at the regional level and across countries. Trend analyses of climatic variability detected that the annual average temperature rose significantly between 1970 and 2015 in Africa. Conversely, we did not find significant annual average rainfall trends in most countries, except for Burkina Faso, Mali, and the Gambia. However, on examination of the food security model that accounted for climate change and other control variables, rainfall was found to play a decisive role in Africa's food security in the long run.

On the other hands, we did not detect robust evidence that temperature influences food security in Africa in the long run. In the short run, temperature was found to impede food security, whereas rainfall was positively associated with food security. Intriguingly, these climatic conditions had an inconclusive impact on food security overall as their effects varied dramatically among countries when we evaluated magnitude and direction. The study further indicated that a bidirectional causality exists between food security and temperature, cultivated areas and food security, GDP per capita and food security, and population growth and food security. However, the causality between rainfall and food security is unidirectional, with rainfall affecting food security but not vice versa.

These findings have numerous policy implications. First, because rainfall plays a crucial role in Africa's food security, an intervention to reduce the risk of rain-fed farm production is critical, given the extreme variability of rainfall patterns across the continent. Such intervention must involve establishing irrigation infrastructure to assist farmers, especially those in rural areas. Second, policymakers should also encourage financial inclusiveness by strengthening the financial sector to make small-scale loans available to farmers. This suggestion aligns with Baye's (2016) view that governments, donor agencies, and development partners must pursue policies such as increasing land allocation in local land reforms, increasing food production, and investing in agricultural productivity to increase Africa's food supply capacity. More importantly, further research on the subject must incorporate other dimensions of food security, such as food accessibility, food utilisation, and food stability, to present a broader picture of food security across Africa.

Acknowledgements The authors would like to thank the anonymous reviewers for their valuable comments and suggestions.

Author contributions The authors (Robert Becker Pickson and Elliot Boateng) conducted this study. All authors read and approved the final manuscript.

Funding No organization funded this study.

Data availability The data used for this study will be made available upon request.

Declarations

Conflict of interest The authors declared no conflict of interest.

\section{References}

Adhikari, U., Nejadhashemi, A. P., \& Woznicki, S. A. (2015). Climate change and eastern Africa: A review of the impact on major crops. Food and Energy Security, 4(2), 110-132.

Akinbile, C. O., Ogunmola, O. O., Abolude, A. T., \& Akande, S. O. (2020). Trends and spatial analysis of temperature and rainfall patterns on rice yields in Nigeria. Atmospheric Science Letters, 21(3), e944. 
Amekudzi, L. K., Yamba, E. I., Preko, K., Asare, E. O., Aryee, J., Baidu, M., \& Codjoe, S. N. (2015). Variabilities in rainfall onset, cessation, and length of the rainy season for the various agro-ecological zones of Ghana. Climate, 3(2), 416-434.

Antwi-Agyei, P. (2012). Vulnerability and adaptation of Ghana's food production systems and rural livelihoods to climate variability. Unpublished Doctoral Dissertation Submitted to the School of Earth and Environment, The University of Leeds, United Kingdom.

Arnell, N. (2009). Beyond $4^{\circ}$ C: Impacts across the global scale. Retrieved September 25, 2020 from: http:// www.eci.ox.ac.uk/4degrees/ppt/1-3arnell.pdf.

Asian Development Bank. (2012.) Food Security and poverty in asia and the Pacific: Key challenges and policy issues. Asian Development Bank, Philippines (Manila). Retrieved October 3, 2020 from https:// reliefweb.int/sites/reliefweb.int/files/resources/food-security-poverty.pdf.

Barrera, E. L., \& Hertel, T. (2021). Global food waste across the income spectrum: Implications for food prices, production and resource use. Food Policy, 98, 101874. https://doi.org/10.1016/j.foodpol.2020. 101874

Baye, R. S. (2016). Assessing Trade Liberalisation on Food Security in Sub-Saharan Africa. Unpublished Master's Thesis Submitted to the University of Ghana, Legon. Retrieved September 29, 2020 from http://ugspace.ug.edu.gh/handle/123456789/23320.

Bezuneh, M., \& Yiheyis, Z. (2014). Has trade liberalization improved food availability in developing countries? An empirical analysis. Journal of Economic Development, 39(1), 63-78.

Boko, M., Niang, I., Nyong, A., Vogel, C., Githeko, A., Medany, M., Osman-Elasha, B., Tabo, R., \& Yanda, P. (2007). In Parry ML, Canziani OF, Palutikof JP, Van Der Linden PJ, Hanson CE (Eds.), Impacts, adaptation, and vulnerability. Contribution of working group II to the fourth assessment report of the intergovernmental panel on climate change. Cambridge: Cambridge University Press, pp. (433-467)

Brown, O., Hammill, A., \& McLeman, R. (2007). Climate change as the "new" security threat: Implications for Africa. International Affairs, 83(6), 1141-1154.

Burke, M. B., Miguel, E., Satyanath, S., Dykema, J. A., \& Lobell, D. B. (2009). Warming increases the risk of civil war in Africa. Proceedings of the National Academy of Sciences, 106(49), 20670-20674.

Byrnes, B. H., \& Bumb, B. L. (1998). Population growth, food production and nutrient requirements. Journal of Crop Production, 1(2), 1-27.

Chauhan, N., Shukla, R., \& Joshi, P. K. (2020). Assessing the inherent vulnerability of farming communities across different biogeographical zones in Himachal Pradesh India. Environmental Development, 33, 100506. https://doi.org/10.1016/j.envdev.2020.100506

Choi, I. (2001). Unit root tests for panel data. Journal of International Money and Finance, 20(2), $249-272$.

Christensen, J. H., Hewitson, B., Busuioc, A., Chen, A., Gao, X., Held, R., Jones, R., Kolli, R. K., Kwon, W., \& Laprise, R. (2007). Regional climate projections: Climate change (2007): The physical science basis. Contribution of working group I to the fourth assessment report of the intergovernmental panel on climate change. University Press.

Connolly-Boutin, L., \& Smit, B. (2016). Climate change, food security, and livelihoods in sub-Saharan Africa. Regional Environmental Change, 16(2), 385-399.

Cooper, P. J. M., Dime, J., Rao, K. P. C., Shapiro, B., Shiferaw, B., \& Twomlow, S. (2008). Coping better with current climatic variability in the rain-fed farming systems of sub-Saharan Africa: An essential first step in adapting to future climate change? Agriculture, Ecosystems and Environment, 126(1-2), 24-35. https://doi.org/10.1016/j.agee.2008.01.007

Dadzie, S. K. N., Inkoom, E. W., Akaba, S., Annor-Frempong, F., \& Afful, J. (2021). Sustainability responses to climate-smart adaptation in Africa: Implication for food security among farm households in the Central Region of Ghana. African Journal of Economic and Management Studies. https://doi. org/10.1108/AJEMS-04-2019-0155

Demeke, A. B., Keil, A., \& Zeller, M. (2011). Using panel data to estimate the effect of rainfall shocks on smallholders' food security and vulnerability in rural Ethiopia. Climatic Change, 108(1-2), 185-206.

Dogan, E., Seker, F., \& Bulbul, S. (2017). Investigating the impacts of energy consumption, real GDP, tourism and trade on $\mathrm{CO} 2$ emissions by accounting for cross-sectional dependence: A panel study of OECD countries. Current Issues in Tourism, 20(16), 1701-1719.

Dogliotti, S., García, M. C., Peluffo, S., Dieste, J. P., Pedemonte, A. J., Bacigalupe, G. F., \& Chiappe, M. (2014). Co-innovation of family farm systems: A systems approach to sustainable agriculture. Agricultural Systems, 126, 76-86. https://doi.org/10.1016/j.agsy.2013.02.009

Douglas, E. M., Vogel, R. M., \& Kroll, C. N. (2000). Trends in floods and low flows in the United States: Impact of spatial correlation. Journal of Hydrology, 240, 90-105.

Drexhage, J.R., \& Murphy, D. (2010). Climate change and foreign policy in Canada: Intersection and influence. Canadian International Council. Retrieved September 25, 2020 from http://citeseerx.ist.psu.edu/ viewdoc/download?doi=10.1.1.172.4956\&rep=rep1\&type $=$ pdf. 
Dumitrescu, E. I., \& Hurlin, C. (2012). Testing for Granger non-causality in heterogeneous panels. Economic Modelling, 29(4), 1450-1460.

Easterling, D. R., Meehl, G. A., Parmesan, C., Changnon, S. A., Karl, T. R., \& Mearns, L. O. (2000). Climate extremes: Observations, modelling, and impacts. Science, 289(5487), 2068-2074.

Easterling, W., Aggarwal, P., Batima, P., Brander, K., Bruinsma, J., Erda, L., Howden, M., Tubiello, F., Antle, J., \& Baethgen, W. (2007). Food, fibre, and forest products. In M. L. Parry, O. F. Canziani, J. P. Palutikof, P. J. Van Der Linden, \& C. E. Hanson (Eds.), Impacts, adaptation, and vulnerability. Contribution of working group II to the fourth assessment report of the intergovernmental panel on climate change. Cambridge University Press.

Elbehri, A. (2015). Climate change and food systems: Global assessments and implications for food security and trade. Food and Agriculture Organization of the United Nations.

ElNesr, M. N., Abu-Zreig, M. M., \& Alazba, A. A. (2010). Temperature trends and distribution in the Arabian Peninsula. American Journal of Environmental Sciences, 6(191-203), 2010.

Etana, D., van Wesenbeeck, C. F., \& de Cock Buning, T. (2021). Socio-cultural aspects of farmers' perception of the risk of climate change and variability in Central Ethiopia. Climate and Development, 13(2), 139-151.

Faisal, I. M., \& Parveen, S. (2004). Food security in the face of climate change, population growth, and resource constraints: implications for Bangladesh. Environmental Management, 34(4), 487-498.

Food and Agriculture Organisation. (2005). Impact of climate change, pests and diseases on food security and poverty reduction. In Proceedings of the FAO Committee on World Food Security (31st Session), Rome, Italy.

Food and Agriculture Organisation. (2008). Climate change and food security: A framework for action. Food and Agriculture Organisation of the United Nations.

Food and Agriculture Organisation. (2010). Climate change implications for food security and natural resources management in Africa. Twenty-sixth regional conference for Africa. 03 - 07 May 2010. Rome: Food and Agriculture Organisation of the United Nations.

Food and Agriculture Organisation. (2019). Food and Agriculture Data. http://www.fao.org/faostat/en/\# data.

Food and Agriculture Organisation, International Fund for Agricultural Development, United Nations International Children's Emergency Fund, World Food Programme, \& the World Health Organisation. (2020). The State of Food Security and Nutrition in the World 2020: Transforming food systems for affordable healthy diets. Rome: Food \& Agriculture Organisation of the United Nations. https://doi.org/10.4060/ca9692en. Retrieved March 20, 2021 from http://www.fao.org/3/ca9692en/ online/ca9692en.html.

Food and Agriculture Organisation, International Fund for Agricultural Development, United Nations International Children's Emergency Fund, World Food Programme, \& the World Health Organisation. (2019). The state of food security and nutrition in the world 2019. Safeguarding against Economic Slowdowns and Downturns. Rome: Food and Agriculture Organization of the United Nations. Retrieved September 20, 2020 from http://www.fao.org/3/ca5162en/ca5162en.pdf.

Fukase, E., \& Martin, W. J. (2017). Economic growth, convergence, and world food demand and supply (No. 8257). The World Bank. http://hdl.handle.net/10986/28918.

Gocic, M., \& Trajkovic, S. (2013). Analysis of changes in meteorological variables using Mann-Kendall and Sen's slope estimator statistical tests in Serbia. Global and Planetary Change, 100, 172-182.

Hossain, M. S., Arshad, M., Qian, L., Zhao, M., Mehmood, Y., \& Kächele, H. (2019). The economic impact of climate change on crop farming in Bangladesh: An application of the Ricardian method. Ecological Economics, 164, 106354. https://doi.org/10.1016/j.ecolecon.2019.106354

Hulme, M., Doherty, R., Ngara, T., New, M., \& Lister, D. (2001). African climate change: 1900-2100. Climate Research, 17(2), 145-168.

Im, K. S., Pesaran, M. H., \& Shin, Y. (2003). Testing for unit roots in heterogeneous panels. Journal of Econometrics, 115(1), 53-74.

Intergovernmental Panel on Climate Change. (2001). Impacts, adaptation, and vulnerability. Contribution of working group II to the third assessment report of the Intergovernmental Panel on Climate Change. Cambridge University Press, Cambridge, UK.

Kendall, M. (1975). Rank correlation methods. Griffin.

Kim, D. H., Lin, S. C., \& Suen, Y. B. (2010). Dynamic effects of trade openness on financial development. Economic Modelling, 27(1), 254-261.

Kotir, J. H. (2011). Climate change and variability in Sub-Saharan Africa: A review of current and future trends and impacts on agriculture and food security. Environment, Development, and Sustainability, 13, 587-605. https://doi.org/10.1007/s10668-010-9278-0 
Levin, A., Lin, C. F., \& Chu, C. S. (2002). Unit root tests in panel data: Asymptotic and finite-sample properties. Journal of Econometrics, 108(1), 1-24.

Lobell, D. B., Bänziger, M., Magorokosho, C., \& Vivek, B. (2011). Nonlinear heat effects on African maize as evidenced by historical yield trials. Nature Climate Change, 1(1), 42-45.

Maddala, G. S., \& Wu, S. (1999). A comparative study of unit root tests with panel data and a new simple test. Oxford Bulletin of Economics and Statistics, 61(S1), 631-652.

Mann, H. B. (1945). Nonparametric tests against trend. Econometrica, 13(245-259), 1945. https://doi.org/ $10.2307 / 1907187$

McCarl, B. A., Fernandez, M. A., Jones, J. P., \& Wlodarz, M. (2013). Climate change and food security. Current History, 112(750), 33-37.

McCarthy, J. J., Canziani, O. F., Leary, N. A., Dokken, D. J., \& White, C. (2001). Impacts, adaptation, and vulnerability. Contribution of working group II to the third assessment report of the intergovernmental panel on climate change. Cambridge University Press.

Mendelsohn, R., \& Wang, J. (2017). The impact of climate on farm inputs in developing countries agriculture. Atmósfera, 30(2), 77-86.

Miheretu, B. A. (2020). Temporal variability and trend analysis of temperature and rainfall in the Northern highlands of Ethiopia. Physical Geography. https://doi.org/10.1080/02723646.2020.1806674

Modarres, R., \& Silva, V. P. R. (2007). Rainfall Trends in Arid and Semi-Arid Regions of Iran. Journal of Arid Environments, 70, 344-355.

Muchuru, S., \& Nhamo, G. (2019). A review of climate change adaptation measures in the African crop sector. Climate and Development, 11(10), 873-885.

Nakhooda, S., Caravani, A., Bird, N., Schalatek, L., \& America, H. B. S. N. (2011). Climate finance in subSaharan Africa. Climate Finance Policy Briefs, Heinrich Böll Stiftung North America, Washington, $D C$, USA and Overseas Development Institute (ODI), London, UK.

Nathaniel, S., Barua, S., Hussain, H., \& Adeleye, N. (2021). The determinants and interrelationship of carbon emissions and economic growth in African economies: Fresh insights from static and dynamic models. Journal of Public Affairs, 21(1), e2141. https://doi.org/10.1002/pa.2141

Nelson, G. C., Rosegrant, M. W., Koo, J., Robertson, R., Sulser, T., Zhu, T., Ringler, C., Msangi, S., Palazzo, A., Batka, M., Magalhaes, M., Valmonte-Santos, R., Ewing, M., \& Lee, D. (2009). Climate change impact on agriculture and costs of adaptation. Food policy report. International Food Policy Research Institute.

Nicholson, S. E. (2001). Climatic and environmental change in Africa during the last two centuries. Climate Research, 17(2), 123-144.

Nicholson, S. E., Some, B., \& Kone, B. (2000). An analysis of recent rainfall conditions in West Africa, including the rainy seasons of the $1997 \mathrm{El} \mathrm{Niño} \mathrm{and} \mathrm{the} 1998 \mathrm{La}$ Niña years. Journal of Climate, 13(14), 2628-2640.

Ofori-Abebrese, G., \& Pickson, R. B. (2018). Ricardian Equivalence Hypothesis in the Sub-Saharan African Countries. Journal of Economic Integration, 33(3), 466-487.

Olivier, J. G. J., \& Peters, J. A. H. W. (2020). Trends in global $\mathrm{CO}_{2}$ and total greenhouse gas emissions: 2019 report. PBL Netherlands environmental assessment agency, The Hague. Retrieved September 25, 2020 from https://www.pbl.nl/sites/default/files/downloads/pbl-2020-trends-in-global-co2-and-totalgreenhouse-gas-emissions-2019-report_4068.pdf.

Owusu, V., Ma, W., Emuah, D., \& Renwick, A. (2021). Perceptions and vulnerability of farming households to climate change in three agro-ecological zones of Ghana. Journal of Cleaner Production, 293, 126154. https://doi.org/10.1016/j.jclepro.2021.126154

Partal, T., \& Kahya, E. (2006). Trend analysis in Turkish precipitation data. Hydrological Processes, 20, 2011-2026.

Pesaran, M. H., Shin, Y., \& Smith, R. P. (1999). Pooled mean group estimation of dynamic heterogeneous panels. Journal of the American Statistical Association, 94(446), 621-634. https://doi.org/10.1080/ 01621459.1999 .10474156

Pesaran, M. H., Shin, Y., \& Smith, R. J. (2001). Bounds testing approaches to the analysis of level relationships. Journal of Applied Econometrics, 16(3), 289-326.

Pickson, R. B., He, G., Ntiamoah, E. B., \& Li, C. (2020). Cereal production in the presence of climate change in China. Environmental Science and Pollution Research, 27(36), 45802-45813. https://doi. org/10.1007/s11356-020-10430-x

Ribaudo, M., Delgado, J., Hansen, L., Livingston, M., Mosheim, R., \& Williamson, J. (2011). Nitrogen in agricultural systems: Implications for conservation policy. USDA-ERS Economic Research Report No. (ERR-127). Retrieved September 25, 2020 from https:/www.ers.usda.gov/publications/pub-details/? pubid $=44919$. 
Schlenker, W., \& Lobell, D. B. (2010). Robust negative impacts of climate change on African agriculture. Environmental Research Letters, 5, 014010.

Sen, P. K. (1968). Estimates of the Regression Coefficient Based on Kendall's Tau. Journal of American Statistical Association, 63, 1379-1389.

Shah, M., Fischer, G., \& van Velthuizen, H. (2008). Food security and sustainable agriculture. The challenges of climate change in sub-Saharan Africa. International Institute for Applied Systems Analysis.

Singh, S. P., \& Thadani, R. (2015). Complexities and controversies in Himalayan research: A call for collaboration and rigour for better data. Mountain Research and Development, 35(4), 401-409.

Smith, L. C., \& Haddad, L. (2001). How important is improving food availability for reducing child malnutrition in developing countries? Agricultural Economics, 26(3), 191-204.

Sy, A. (2016). Africa: Financing adaptation and mitigation in the world's most vulnerable region. Africa: Brookings Institution, Africa Growth Initiative. Retrieved September 25, 2020 from https://www.brook ings.edu/wp-content/uploads/2016/08/global_20160818_cop21_africa.pdf.

Tabari, H., \& Marofi, S. (2011). Changes of pan evaporation in the west of Iran. Water Resources Management, 25, 97-111.

Tabari, H., Marofi, S., Aeini, A., Hosseinzadeh, T. P., \& Mohammadi, K. (2011). Trend analysis of reference evapotranspiration in the western half of Iran. Agricultural and Forest Meteorology, 151(2), 128-136.

Tabari, H., Shifteh, S. B., \& Rezaeian, Z. M. (2011). Testing for long-term trends in climatic variables in Iran. Atmospheric Research, 100(1), 132-140.

Tankari, M. R. (2020). Rainfall variability and farm households' food insecurity in Burkina Faso: Nonfarm activities as a coping strategy. Food Security, 1-12, 567-578.

Thompson, H. E., Berrang-Ford, L., \& Ford, J. D. (2010). Climate change and food security in Sub-Saharan Africa: A systematic literature review. Sustainability, 2, 2719-2733.

Thornton, P. K., Jones, P. G., Ericksen, P. J., \& Challinor, A. J. (2011). Agriculture and food systems in subSaharan Africa in a $4^{\circ} \mathrm{C}+$ world. Philosophical Transactions of the Royal Society A: Mathematical, Physical and Engineering Sciences, 369(1934), 117-136.

United Nations General Assembly. (2015). Transforming our world: the 2030 Agenda for Sustainable Development, October 21, 2015, A/RES/70/1. Retrieved 30 March 2021 from https://www.refworld.org/ docid/57b6e3e44.html.

van den Bos Verma, M., de Vreede, L., Achterbosch, T., \& Rutten, M. M. (2020). Consumers discard a lot more food than widely believed: Estimates of global food waste using an energy gap approach and affluence elasticity of food waste. PLOS ONE, 15(2), e0228369. https://doi.org/10.1371/journal.pone. 0228369

Wong, H., Wei, X., Kahsay, H. B., Gebreegziabher, Z., Gardebroek, C., Osgood, D. E., \& Diro, R. (2020). Effects of input vouchers and rainfall insurance on agricultural production and household welfare: Experimental evidence from northern Ethiopia. World Development, 135, 105074.

World Bank. (2019). World development indicators. http://datatopics.worldbank.org/world-developmentindicators/.

World Meteorological Organisation. (2020). Carbon dioxide levels continue at record levels, despite the COVID-19 lockdown. World Meteorological Organisation (Press Release Number: 23112020), Geneva, Switzerland. Retrieved March 19, 2021 from https://public.wmo.int/en/media/press-release/ carbon-dioxide-levels-continue-record-levels-despite-covid-19-lockdown.

Yang, R. Y., \& Hanson, P. M. (2009). Improved food availability for food security in Asia-Pacific Region. Asia Pacific Journal of Clinical Nutrition, 18(4), 633-637.

Yobom, O. (2020). Climate change and variability: Empirical evidence for countries and agro-ecological zones of the Sahel. Climatic Change, 159, 365-384. https://doi.org/10.1007/s10584-019-02606-3

Yue, S., \& Hashino, M. (2003). Temperature trends in Japan: 1900-1996. Theoretical and Applied Climatology, 75(15-27), 2003.

Yue, S., Pilon, P., Phinney, B., \& Cavadias, G. (2002). The influence of autocorrelation on the ability to detect trends in hydrological series. Hydrological Processes, 16, 1807-1829.

Yunling, H., \& Yiping, Z. (2005). Climate change from 1960 to 2000 in the Lancang River Valley China. Mountain Research and Development, 25(4), 341-348.

Publisher's Note Springer Nature remains neutral with regard to jurisdictional claims in published maps and institutional affiliations. 